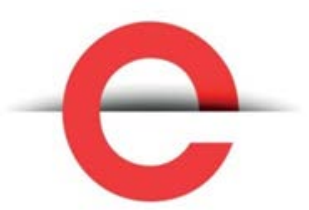

U T S

e P R E S S

Cosmopolitan

Civil Societies: an

Interdisciplinary

Journal

Vol. 9, No. 3

2017

(C) 2017 Alanna Kamp, Oishee Alam, Kathleen Blair, Kevin Dunn. This is an Open Access article distributed under the terms of the Creative Commons Attribution 4.0 Unported (CC BY 4.0) License (https:// creativecommons.org/ licenses/by/4.0/), allowing third parties to copy and redistribute the material in any medium or format and to remix, transform, and build upon the material for any purpose, even commercially, provided the original work is properly cited and states its license.

Citation: Kamp, A., Alam, O., Blair, K. and Dunn, K. 2017. Australians' Views on Cultural Diversity, Nation and Migration, 2015-16. Cosmopolitan Civil Societies: an Interdisciplinary Journal. 9(3), 61-84. http://dx.doi.org/10.5130/ccs.v9i $\underline{3.5635}$

ISSN 1837-5391 Published by UTS EPRESS | mcs.epress.lib.uts.edu.au
REFEREED PAPER

\section{Australians' Views on Cultural Diversity, Nation and Migration, 2015-16}

\author{
Alanna Kamp, Oishee Alam, Kathleen Blair, Kevin Dunn \\ Western Sydney University, Australia
}

Corresponding author: Alanna Kamp, Urban Research Program/School of Social Sciences and Psychology, Western Sydney University, Locked Bag 1797 Penrith NSW 2751 Australia. A.Kamp@westernsydney.edu.au

DOI: http://dx.doi.org/10.5130/ccs.v9i3.5635

\begin{abstract}
Between July and August 2015, and in November 2016, the Challenging Racism Project team conducted an online survey to measure the extent and variation of racist attitudes and experiences in Australia. The survey comprised a sample of 6001 Australian residents, which was largely representative of the Australian population. The survey gauged Australians' attitudes toward cultural diversity, intolerance of specific groups, immigration, perceptions of Anglo-Celtic cultural privilege, and belief in racialism, racial separatism and racial hierarchy. In this paper we report findings on respondents' views on cultural diversity, nation and migration. The majority of Australians are pro-diversity. However, we also acknowledge conflicting findings such as strong support for assimilation and identification of 'out groups'. The findings paint a complex picture of attitudes towards cultural diversity, nation and migration in Australia. The attitudes reflect contradictory political trends of celebrated diversity, triumphalist claims about freedom, alongside pro-assimilationist views and stoked Islamophobia. This is within the context of a stalled multicultural project that has not sufficiently challenged assimilationist assumptions and Anglo-privilege.
\end{abstract}

\section{Keywords}

Cultural diversity; racism; multiculturalism; Australia; survey; quantitative research 


\section{Introduction}

Recent changes to Australia's social, demographic and geopolitical landscape have made the need to closely examine Australians' views on cultural diversity, nation and migration even more imperative as such examinations allow us to better understand how macro-level processes may affect intergroup relations and attitudes. Data from the 2016 Australian National Census indicate that the cultural and religious face of Australia is continuing to transform at a rapid rate. Buddhism, Hinduism, Sikhism and Islam have all experienced an increase in adherents while adherence to Christianity has fallen, and almost one in two Australians report that one or both of their parents were born overseas (ABS 2017a). This is further supported by the finding that 27 per cent of Australians speak a language other than English at home (with over 200 languages spoken across the country), an increase of 4 percent from the previous Census in 2011. Much of this change can be attributed to migration via Australia’s Migration Program and Humanitarian Program, which see close to 200,000 permanent migrants moving to Australia annually, from countries including New Zealand, the United Kingdom, China, India and the Philippines (ABS 2017a).

The picture of multicultural Australia provided by the Census is complicated, however, by concurrent political initiatives, policy and legislative changes, grassroots social movements and media commentary that at times bolster and at other times protest the demographic reality of cultural diversity in Australia. For example, migration to Australia has been tempered by proposed and actual changes to Australia's migration and multiculturalism policies in recent years, most notably the abolition of 457 visas (Temporary Work (Skilled) visas) and proposed changes to citizenship laws that would make it more difficult for residents to attain citizenship (Department of Immigration and Border Protection 2017). While proposed changes to citizenship laws failed to pass the Senate in late 2017, it has been indicated that the debate continues, as a redraft of reforms is imminent (Zivic 2017). Fifty years since the 1967 referendum to include Aboriginal Australians in the census, and ten years since the highly criticised Northern Territory intervention into remote Aboriginal communities, Aboriginal people in Australia continue to be marginalised politically, economically, and socially (McGregor 2011, Moore 2014). Reported experiences of racism and Islamophobia have remained high for several years, with a 2015 report on Muslim experiences in Australia finding that 57 per cent of Muslim Australian respondents had experienced racism (Dunn et al 2015). Such increases in racist incidents have coincided with a (failed) political attempt to amend/repeal Section 18C of the Racial Discrimination Act-a legislative protection from 'offensive behaviour because of race, colour or national or ethnic origin’ (Racial Discrimination Act 1975, s.18C). Australia's formal humanitarian intake of asylum seekers and refugees coexists alongside its policy of indefinite detention in offshore centres for asylum seekers arriving by sea, and government and media discourse that vilifies asylum seekers and feeds anti-asylum seeker sentiments (Augoustinos and Quinn 2003; Pedersen et al. 2006; Every and Augoustinos 2007; McKay et al 2012, Trounson et al 2015). Our anticipation is that these contradictory political discourses and the demographic realities will be reflected in contradictory attitudes on Australian multiculturalism. This contradiction and protest is important insofar as it contributes to intergroup tensions and intolerances. 
Australia's story of migration and multiculturalism has drawn the attention of researchers interested in documenting Australians' attitudes toward the sometimes polarising issues of cultural diversity, migration and nation. For example, Betts' (1996) analysis of polls on attitudes toward immigration from 1961 to 1996 indicates that opposition to immigration had remained high in Australia since the 1980s. Two thirds of Australians polled opposed immigration in 1996 (see Betts 1996, p. 10). However, this picture changed in the years following Betts' original article, and by 2002 she noted that opposition to immigration had decreased. This was attributed to lower unemployment, lowered intake of immigration, and a decrease in fears about population growth (Betts 2002; see also McAllister 1993).

The Geographies of Racism Survey conducted by The Challenging Racism Project (2001-2008) found that attitudes toward cultural diversity were somewhat contradictory. Of the 12,512 survey participants, 85 per cent agreed that cultural diversity is beneficial for society, but 45 per cent of respondents believing that ethnic diversity weakens nations. These findings appear to support a much smaller-scale survey conducted over a decade previously of only Anglo, Australian-born respondents, in which only 42 per cent of respondents stated that multiculturalism contributed to social cohesion, and over a third of respondents indicated that it led to more intergroup conflict (Ho 1990, p. 266). The research findings of Ang et al. (2002) were more optimistic, with two-thirds of their national sample of 1,439 respondents stating they believed immigration had been beneficial to Australia, 52 per cent supported multiculturalism and 59 per cent supported cultural diversity. Perhaps unsurprisingly, support was much higher among their representative NESB (Non-English Speaking Background) samples of Filipino, Greek, Lebanese, Somali and Vietnamese speakers (Ang et al. 2002, p. 9). This research story on attitudes towards multiculturalism is one that charts a movement towards broader support, but which also unearths continuing, though eroding, support for assimilation.

An important factor to consider when examining public opinion on cultural diversity, nation and migration is Australians' attitudes towards stigmatised ethnic groups. Dunn et al. (2004, p.415) found that despite the majority of respondents articulating that they were comfortable with cultural diversity, intolerant attitudes towards some 'out groups' were high, particularly toward Aboriginal and Muslim Australians. Intolerant attitudes towards these and other out groups remained high throughout the course of the project, and questions on experiences of racism found that close to one-in-five respondents had experienced racist talk. These findings indicate that racism is prevalent in Australian society despite high levels of support for cultural diversity (Dunn et al. 2004).

Another significant dataset on multiculturalism and social cohesion can be found in the Scanlon Foundation's 'Mapping Social Cohesion' reports, which document annual research on Australian attitudes to cultural diversity from 2007. Their most recent survey, conducted in 2016, found that 22 per cent of respondents were strongly positive toward cultural diversity and 10-12 per cent were strongly negative - an increase of two percent since the previous year (Markus 2016). Markus (2016, p.53) argues that the small proportion of people who oppose immigration and support assimilation policies demonstrate how far attitudes have shifted since the end of the White Australia Policy. There were, however, outliers to the 
broad positivity toward cultural diversity documented in the 2016 report, with almost 42 per cent of respondents indicating a strongly negative response to asylum seekers arriving in Australia by boat, and a quarter of respondents expressing negative attitudes toward Muslims. Overall, Markus (2016) identified that there was a slight increase in negative attitudes toward cultural diversity and specific out groups in 2016.

In addition to reporting on the public opinion of Australians, scholars have investigated why some attitudes are more prevalent than others particularly in relation to contemporary social, political and economic concerns. As mentioned previously, Betts' (1996) research illuminated that anxiety about unemployment, crime and security and population growth often fuelled opposition to immigration in the late Twentieth Century. The qualitative component of Dandy and Pe-Pua's (2010) mixed-methods research in three Australian states found that cultural diversity was perceived as negative to society because of factors such as divisiveness (cultural groups 'sticking together' and not integrating into mainstream Australian society), the existence of racism, intergroup conflict from overseas being 'imported' into Australia, crime, and social inequality (see Dandy and Pe-Pua 2010, p. 43). Dandy and Pe-Pua (2010) also uncovered that cultural diversity was positively viewed by some respondents due to perceptions of cultural enrichment, a broadening of perspective and worldview, a more positive intergroup attitude, and benefits to the Australian economy. Such research highlights the utility of qualitative methods in investigating the nuances and complexities of Australians’ perspectives on cultural diversity, racism and migration.

This paper contributes to the existing body of literature by providing current and national-level findings on Australians' attitudes toward cultural diversity, nation and migration, through an analysis of participants' responses to eight survey questions. After detailing the data collection and analysis methods and their limitations, we discuss the findings of the survey in relation to three key topic areas: attitudes to cultural diversity, the identification of 'out groups' in Australian society, and perceptions of Australian immigration intake. While we acknowledge that the standardised quantitative measures used and quantitative data analysed in this paper may not fully illuminate the complexity of Australians' attitudes and personal perspectives, our empirical findings provide an important, extensive and up-to-date basis for further investigations.

\section{Method: Survey Data Collection and Analysis}

Between July and August 2015 and in November 2016, the Challenging Racism Project conducted a survey that gauged the extent and variation of racist attitudes and experiences of racism in Australia ${ }^{1}$. The survey data were collected via an online questionnaire (provided through a commercial survey provider) with a final sample of 6001 Australian respondents ${ }^{2}$. The only criteria for participation in this survey were that participants be Australian residents and 18 years of age or older.

\footnotetext{
${ }^{1}$ This research was commissioned by the Special Broadcasting Service (SBS) for the documentary titled 'Is Australia racist?' released on 26 February 2017.

2 The first recruitment phase took place between July and August 2015 and resulted in 5407 participants. The second recruitment phase too place in November 2016 and resulted in 594 participants.
} 
Participants were recruited from the 400,000 individuals who are active panellists of the commercial online panel provider, SSI (Survey Sampling Inc.). SSI employs rigorous quality controls, recruits participants in a variety of ways to ensure a diverse sample, and randomly selects panel participants to complete the surveys. It is acknowledged that there may be various limitations in utilising online panels in survey research such as the relationship between completion rates and data accuracy and the relationship between multiple panel memberships and data quality, however, these limitations are not yet well examined (Callegaro et al. 2014; Baker et al. 2010). One obvious limitation of this survey design is that participants must have access to the internet and be registered panellists of SSI.

Despite recruitment limitations, the final sample for this project was largely representative of the broader Australian population. For example, 51.7 per cent of respondents were female and 48.4 per cent were male. This proportion closely approximates the representation of males and females in the Australian population (50.7 per cent female and 49.3 per cent male according to the Australian Bureau of Statistic ((ABS) 2017b). In regards to state/territory of residence, 1.1 per cent of respondents were from the Australian Capital Territory; 32.9 per cent from New South Wales; 20.4 per cent from Queensland; 0.9 per cent from the Northern Territory; 9.9 per cent from Western Australia; 7.5 per cent from South Australia; 25.4 per cent from Victoria; and 2.0 per cent from Tasmania. Again, this closely approximates the relative population sizes of the states and territories (ABS 2017b). In terms of educational representation, individuals who have completed a university degree and/or postgraduate qualification were over-represented in the sample with 23.8 percent of participants having achieved a university degree and an additional 11.3 per cent having achieved a postgraduate qualification. This compares to 16.1 per cent of the Australian population that had completed their education at a university or other tertiary institution (ABS 2017b).

The sample was also culturally and religiously diverse. The majority of participants (72.2 per cent) were born in Australia, with other common countries of birth being the United Kingdom (7.6 per cent), New Zealand (2.4 per cent), India (2.4 per cent), Malaysia (1.4 per cent) and China (1.1 per cent excluding SARs and Taiwan). Almost half the sample (48.8 per cent) had at least one parent who was born overseas. Of the total sample 2.3 per cent of the participants identified as being of Aboriginal or Torres Strait Islander background. This proportion closely approximates the total Australian population who are of Aboriginal or Torres Strait Islander descent (2.8 percent as stated by the ABS 2017b). The cultural diversity of the sample was also reflected in the languages spoken at home. Respondents who speak a language other than English at home comprised 18.3 per cent of the sample with the most common languages (besides English) being Cantonese (1.6 per cent), Mandarin (1.3 per cent), Italian (1.3 per cent), Greek (0.9 per cent), 'Chinese' (0.9 per cent), Hindi (0.9 per cent, Vietnamese ( 0.8 per cent), and Arabic ( 0.6 per cent). Again, this was a close reflection of the broader Australian population as documented by the ABS (2017b). The majority of participants claimed no religion (38.2 per cent) followed by religious affiliations with Christianity (50.2 per cent), Buddhism (2.8 per cent), Hinduism (2.2 per cent), Islam (1.6 per cent) and Judaism (0.7 per cent). 
In line with the survey's aim, the online questionnaire included thirty primary ${ }^{3}$ questions/statements relating to attitudes towards issues such as racism and anti-racism, multiculturalism and religious diversity in Australia, and migration, asylum seekers and refugees. Three primary questions/statements relating to experiences of racism/racial discrimination were also included in the questionnaire as well as a variety of demographic questions such as participants' age, level of education, labour force participation, gender, state/territory of residence, country of birth and religion (see Challenging Racism Project 2017a for a full list of questions). In this paper we report findings on respondents' views on cultural diversity, nation and migration by drawing upon responses to the eight questions/statements that focused on judgements on the benefits or weaknesses of cultural diversity, identification of 'out groups' groups (i.e. those that do not fit into Australian society), and perceptions Australia’s immigrant intake.

In order to analyse the quantitative data, questionnaire responses were downloaded into IBM SPSS Software and crosstabulations generated. The crosstabulations were used to summarise the relationship between various demographic variables (age, sex, birthplace, education level etc) and questionnaire responses. In some instances, crosstabulations were also used to gauge relationships between responses to multiple survey questions. The crosstabulations were subjected to statistical analyses including Pearson's chi squared $\left(X^{2}\right)$ test. The Pearson's chi square $\left(X^{2}\right)$ was used to test for the independence between variables that may be theoretically associated, this included for example being born overseas (or not) and dispositions towards cultural diversity. The sample size of the survey is such that false positive findings were possible. However, our cross tabulations were confined to tests of independence between variables that made theoretical sense (e.g. attitude on diversity and birthplace), and the $X^{2}$ were strong. The significance of these effects was measured at $\mathrm{P}<.05$ to test whether the associations had been generated by chance. Bonferroni post hoc tests were not necessary given the strength of the $\mathrm{P}$ Values and $X^{2}$.

\section{Attitudes to Cultural Diversity}

As part of the online questionnaire, survey participants were asked a series of four questions pertaining to their views on cultural diversity in Australia. These questions sought to obtain quantitative data on participants' judgements on the benefits or weaknesses of cultural diversity and attitudes towards assimilation (Tables 1-4). These questions operationalised socalled 'new racisms' (that is, perceptions of differentiation and hierarchies based on cultural distinctiveness and conformity rather than biological differences) as outlined by Jayasuriya (2002, pp.40-42).

Respondents were largely supportive of cultural diversity, with 80.4 per cent agreeing that 'it is a good thing for a society to be made up of different cultures' (Table 1). Similarly, 75.1 per cent of respondents agreed that 'having a multicultural population has been good for Australia' (Table 2). These positive findings align with recent research (since 2000) that has found that Australians are generally supportive of cultural diversity (see for example Dunn et

\footnotetext{
${ }^{3}$ We use the term 'primary' here as several of the attitudinal and experiential questions had multiple components or 'sub-questions'.
} 
al. 2004, p. 425; Ang et al. 2006; Nelson and Dunn 2013; Markus 2014; Blair 2015 ). This is in stark contrast to the predominance of attitudes that opposed multiculturalism in the 1980s and early 1990s (Betts 2002, pp.30-31). As Dunn et al. (2004, p.425) suggest, such positive attitudes in recent times reflect the liberal attitudes to equality of opportunity combined with official celebratory rhetoric and education about multiculturalism (and anti-racism initiatives) in contemporary Australia. Participants' own positive experiences of cultural diversity may be another important factor in such widespread support for Australian multiculturalism (Dunn et al. 2004, p. 425).

Table 1. Support for cultural diversity in Australia, 2015-6

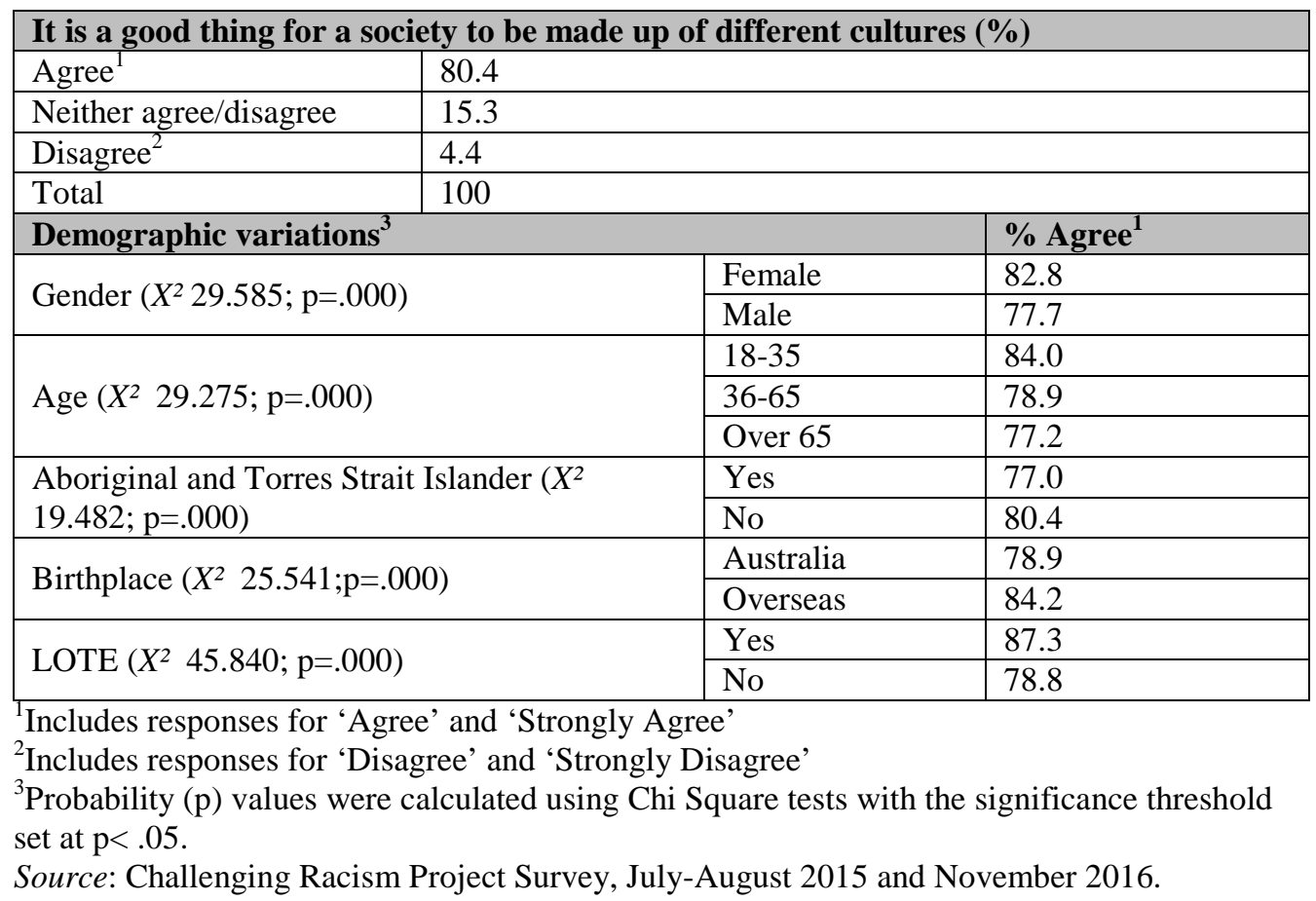

In the responses to the two cultural diversity questions, patterns across various demographic variables were seen. For example, women were more likely than men to be supportive of cultural diversity: 82.8 per cent of women agreed that it is a good thing for a society to be made up of different cultures compared to 77.7 per cent of men (Table 1). Similarly, 76.2 per cent of women agreed that having a multicultural population has been good for Australia, compared to 74.0 per cent of men. In both instances, the gendered differences were statistically significant $\left(X^{2} 29.585 \& 6.053\right)$ with probability values calculated to be less than .05. Across the board, younger Australians between the ages of 18 and 35 have more positive attitudes towards cultural diversity with statistically significant decreases in positive attitudes across the age groups ( $X^{2}$ at $\left.29.275 \& 36.637\right)$. Australians born overseas and those who speak a language other than English were also more likely to be supportive of cultural diversity compared to those born in Australia and those who speak only English (as similarly found by Ang et al. 2002). For example, 84.2 per cent of participants born overseas and 87.3 per cent of participants who speak a language other than English agreed that it is a good thing for society to be made up of different cultures, compared to 78.9 per cent of participants who were born in Australia and 78.8 who only speak English (Table 
1). The differences in attitudes between these groups were statistically significant and a very similar pattern was evident in responses to the question 'Having a multicultural population has been good for Australia' (see Table 2).

Table 2. Support for multiculturalism in Australia, 2015-6

\begin{tabular}{|c|c|c|c|}
\hline \multicolumn{4}{|c|}{ Having a multicultural population has been good for Australia (\%) } \\
\hline Agree $^{1}$ & \multicolumn{3}{|l|}{75.1} \\
\hline Neither agree/disagree & \multicolumn{3}{|l|}{17.1} \\
\hline Disagree $^{2}$ & \multicolumn{3}{|l|}{7.7} \\
\hline Total & \multicolumn{3}{|l|}{100} \\
\hline \multicolumn{3}{|l|}{ Demographic variations $^{3}$} & $\%$ Agree $^{1}$ \\
\hline \multirow{2}{*}{\multicolumn{2}{|c|}{ Gender $\left(X^{2} 6.053 ; \mathrm{p}=.048\right)$}} & Female & 76.2 \\
\hline & & Male & 74 \\
\hline \multirow{3}{*}{\multicolumn{2}{|c|}{ Age $\left(X^{2} 36.637 ; \mathrm{p}=.000\right)$}} & $18-35$ & 78.1 \\
\hline & & $36-65$ & 74.4 \\
\hline & & Over 65 & 71.2 \\
\hline \multirow{2}{*}{\multicolumn{2}{|c|}{$\begin{array}{l}\text { Aboriginal and Torres Strait Islander }\left(X^{2}\right. \\
7.023 ; \mathrm{p}=.030)\end{array}$}} & Yes & 67.4 \\
\hline & & No & 75.3 \\
\hline \multirow{2}{*}{\multicolumn{2}{|c|}{ Birthplace $\left(X^{2}\right.$ 54.936; $\left.\mathrm{p}=.000\right)$}} & Australia & 72.3 \\
\hline & & Overseas & 81.5 \\
\hline \multirow{2}{*}{\multicolumn{2}{|c|}{ LOTE $\left(X^{2}\right.$ 92.118; $\left.\mathrm{p}=.000\right)$}} & Yes & 86.1 \\
\hline & & No & 72.7 \\
\hline
\end{tabular}

${ }^{1}$ Includes responses for 'Agree' and 'Strongly Agree'

${ }^{2}$ Includes responses for 'Disagree' and 'Strongly Disagree'

${ }^{3}$ Probability (p) values were calculated using Chi Square tests with the significance threshold set at $\mathrm{p}<.05$.

Source: Challenging Racism Project Survey, July-August 2015 and November 2016.

The research findings also indicate that Aboriginal and Torres Strait Islander respondents are slightly less supportive of cultural diversity than respondents of nonIndigenous backgrounds. In response to the question: 'Is it a good thing for society to be made up of different cultures?' 77.0 per cent of Aboriginal and Torres Strait Islander participants agreed (11.9 per cent disagreed) compared to 80.4 per cent of participants of nonIndigenous backgrounds who agreed (and only 4.2 per cent that disagreed) (Table 1). Similarly, when posed with the statement, 'Having a multicultural population has been good for Australia', 67.4 per cent of Aboriginal and Torres Strait Islander respondents agreed (13.3 per cent disagreed), compared to 75.3 per cent of participants of non-Indigenous backgrounds who agreed (and only 7.5 per cent that disagreed) (Table 2). Research conducted by Reconciliation Australia (2016) indicated similar findings. That is, while the majority of all project participants agreed that 'we are better off with many cultural groups', Aboriginal and Torres Strait Islander respondents were slightly less likely to agree (56 per cent) than Australians of non-Indigenous backgrounds (66 per cent) (see Reconciliation Australia 2016, p.58).

The statistically significant difference in attitudes between the Aboriginal and Torres Strait Islander cohort and non-Indigenous cohort found in our study (and similarly reflected in Reconciliation Australia's (2016) report) indicates uneasiness with cultural diversity that is more prevalent among the Aboriginal and Torres Strait Islander cohort. This uneasiness with 
multiculturalism has been documented elsewhere and been linked to the problematic positioning of Aboriginal and Torres Strait Islander peoples within conceptions of multiculturalism which includes them as 'just another ethnic group’(Morrissey and Mitchell 1994, p. 111; see also Dunn et al 2010; Castles 1997, p. 16; Curthoys, 2000, p. 29; van den Berg 2002). Such placement aligns Aboriginal and Torres Strait Islander peoples and their concerns/issues with immigrant identifications that are associated with 'multiculturalism' and as such, erases their unique position as the First Australians and consolidates their position as inferior citizens (Hage 1998, pp.16-17, 24; Dunn et al. 2010, p. 20). It cannot be definitely known from these data, however, whether the higher level of uneasiness towards cultural diversity is linked to the problematic positioning of Aboriginal and Torres Strait Islander peoples within conceptions of Australian multiculturalism, or is linked to other factors such as increased experiences of racism (as documented by Reconciliation Australia 2016, and Dunn et al. 2009, p. 9). Interestingly, in the previous Geographies of Racism Survey conducted by The Challenging Racism Project (2001-2008) which also asked 'Is it a good thing for society to be made up of different cultures?’ rates of agreement were much higher among Aboriginal and Torres Strait Islander respondents and respondents of non-Indigenous backgrounds (90.8 per cent and 93.1 per cent respectively) with no statistically significant difference between the two groups (see Dunn et al 2010: 25). Differences between the 2010 and our 2015/2016 survey may be accounted for in the differing recruitment/sampling techniques used (telephone vs. online) or to changes in Australia's social, demographic and geopolitical landscape over the past 5 or so years. Further (particularly qualitative) research on Aboriginal and Torres Strait Islander peoples' attitudes towards multiculturalism and cultural diversity would shed light on this historical shift in opinion.

Despite majority support for cultural diversity and multiculturalism there was somewhat contradictory support for assimilation. Almost 1-in-2 respondents (48.7 per cent) believed that people from racial, ethnic, cultural and religious minority groups should behave more like 'mainstream Australians' (Table 3). When asked if 'Australia is weakened by people of different ethnic origins sticking to their old ways', 41.2 per cent of the participants agreed (Table 4). This parallels the results of the Geographies of Racism Survey which asked participants the same question and found that over 40 per cent of participants agreed that Australia is weakened by different ethnic groups sticking to their 'old ways' despite strong support for Australian multiculturalism (see Dunn et al. 2004). Dunn et al. (2004) argue that such support for assimilation reflects 'a widely held, and largely unchallenged, assumption that successful societies can only be wrought in circumstances of cultural uniformity’ (p. 426). 
Table 3. Support for assimilation, Australia, 2015-6

\begin{tabular}{|c|c|c|}
\hline \multicolumn{3}{|c|}{$\begin{array}{l}\text { People from racial, ethnic, cultural and religious minority groups should behave more } \\
\text { like mainstream Australians (\%) }\end{array}$} \\
\hline Agree $^{1}$ & \multicolumn{2}{|c|}{48.7} \\
\hline Neither agree/disagree & \multicolumn{2}{|c|}{32.8} \\
\hline Disagree $^{2}$ & \multicolumn{2}{|c|}{18.5} \\
\hline Total & \multicolumn{2}{|c|}{100} \\
\hline \multicolumn{2}{|l|}{ Demographic variations $^{3}$} & $\%$ Agree $^{1}$ \\
\hline \multirow[t]{2}{*}{ Gender $\left(X^{2} 63.010 ; \mathrm{p}=.000\right)$} & Female & 44.2 \\
\hline & Male & 53.5 \\
\hline \multirow[t]{3}{*}{ Age $\left(X^{2} 356.778 ; p=.000\right)$} & $18-35$ & 34.7 \\
\hline & $36-65$ & 53.1 \\
\hline & Over 65 & 64.8 \\
\hline \multirow{2}{*}{$\begin{array}{l}\text { Aboriginal and Torres Strait Islander }\left(X^{2}\right. \\
4.110 ; \mathrm{p}=.128)\end{array}$} & Yes & 45.2 \\
\hline & No & 48.8 \\
\hline \multirow[t]{2}{*}{ Birthplace $\left(X^{2} 8.248 ; \mathrm{p}=.016\right)$} & Australia & 47.6 \\
\hline & Overseas & 51.7 \\
\hline \multirow[t]{2}{*}{ LOTE $\left(X^{2} 40.116 ; \mathrm{p}=<.000\right)$} & Yes & 42.9 \\
\hline & No & 50.1 \\
\hline
\end{tabular}

${ }^{1}$ Includes responses for 'Agree' and 'Strongly Agree'

${ }^{2}$ Includes responses for 'Disagree' and 'Strongly Disagree'

${ }^{3}$ Probability (p) values were calculated using Chi Square tests with the significance threshold set at $\mathrm{p}<.05$.

Source: Challenging Racism Project Survey, July-August 2015 and November 2016.

Table 4. Concern about ethnic diversity weakening nation, Australia, 2015-6

\begin{tabular}{|c|c|c|c|}
\hline \multicolumn{4}{|c|}{$\begin{array}{l}\text { Australia is weakened by people of different ethnic origins sticking to their old ways } \\
(\%)\end{array}$} \\
\hline Agree $^{1}$ & \multicolumn{3}{|c|}{41.2} \\
\hline Neither agree/disagree & \multicolumn{3}{|l|}{28.2} \\
\hline Disagree $^{2}$ & \multicolumn{3}{|l|}{30.6} \\
\hline Total & \multicolumn{3}{|l|}{100} \\
\hline \multicolumn{3}{|l|}{ Demographic variations $^{3}$} & $\%$ Agree $^{1}$ \\
\hline \multirow{2}{*}{\multicolumn{2}{|c|}{ Gender $\left(X^{2} 13.891 ; \mathrm{p}=.001\right)$}} & Female & 39.0 \\
\hline & & Male & 43.5 \\
\hline \multirow{3}{*}{\multicolumn{2}{|c|}{ Age $\left(X^{2} 111.783 ; \mathrm{p}=.000\right)$}} & $18-35$ & 33.9 \\
\hline & & $36-65$ & 42.0 \\
\hline & & Over 65 & 53.7 \\
\hline \multirow{2}{*}{\multicolumn{2}{|c|}{$\begin{array}{l}\text { Aboriginal and Torres Strait Islander }\left(X^{2}\right. \\
1.502 ; \mathrm{p}=.472)\end{array}$}} & Yes & 43.0 \\
\hline & & No & 41.1 \\
\hline \multirow{2}{*}{\multicolumn{2}{|c|}{ Birthplace $\left(X^{2} 2.030 ; \mathrm{p}=.362\right)$}} & Australia & 41.7 \\
\hline & & Overseas & 40.0 \\
\hline \multirow{2}{*}{\multicolumn{2}{|c|}{ LOTE $\left(X^{2}\right.$ 46.763; $\left.\mathrm{p}=.000\right)$}} & Yes & 32.5 \\
\hline & & No & 43.2 \\
\hline
\end{tabular}

${ }^{1}$ Includes responses for 'Agree' and 'Strongly Agree'

${ }^{2}$ Includes responses for 'Disagree' and 'Strongly Disagree'

${ }^{3}$ Probability (p) values were calculated using Chi Square tests with the significance threshold set at $\mathrm{p}<.05$.

Source: Challenging Racism Project Survey, July-August 2015 and November 2016. 
The demographic patterns identified in the responses to the cultural diversity questions were replicated in responses to questions about assimilation. For example, male participants were less likely to support cultural diversity with 53.5 per cent of male respondents agreeing that people from racial, ethnic, cultural and religious minority groups should behave more like mainstream Australians. This compares to 44.2 per cent of female respondents (Table 3). Older Australians, particularly those over 65 years of age, were also more likely to support assimilation (64.8 per cent) compared to only 34.7 per cent of 18-35 year olds and 53.1 per cent of 36-65 year olds (Table 3). Participants who do not speak a language other than English were also more likely to support assimilation (50.1 per cent) compared to those who speak a language other than English (42.9 per cent). These demographic variations were statistically significant and a very similar pattern was evident in responses to the question 'Australia is weakened by people of different ethnic origins sticking to their old ways' (see Table 4).

The misalignment between majority support (three-quarters) for cultural diversity and close to majority support (about half) for assimilation was similarly found by Blair (2015). In her qualitative examination of young Anglo-Australian adults' attitudes towards multiculturalism, Blair (2015 p. 441) argued that while young Anglo-Australians are generally enthusiastic about largely cosmopolitan elements of differing cultures, this enthusiasm is more tempered for those elements of culture (e.g. goods and services) that cannot be easily consumed. With participants displaying 'passionate possession of their Anglo-heritage' a 'counter-discourse of fear, loss of national identity and suspicion of 'others' (Blair 2015, p.441) was evident in focus-group discussions of such things as conflicting religious ideologies, Anglo-Celtic privilege, language, and social enclaves. Blair's (2015) participants believed cultural diversity, or 'too much' of it, was a threat to their nation, their culture and their sense of belonging. As such, like a large proportion of our survey respondents, they expressed simultaneous and contradictory support for cultural diversity and cultural homogeneity.

Support for cultural and racial pluralism alongside concerns about diversity point to anxieties about cultural difference, and cultural distinctiveness, and it is thought that these relate to disquiet about the extent to which people perceive cultural diversity to be well managed (Dunn et al. 2010). Research has found that Australians perceive the management of Australian multiculturalism to involve the exclusion of groups who do not 'fit in' or are incompatible with the Australian national imaginary or culture (see for example Dunn et al. 2004; Nelson and Dunn 2013). As such, there are perceived 'limits' to multiculturalism and the extent to which cultural diversity can be successful/beneficial to the nation. It may be the case, for example, that the benefits of different groups contributing to cultural diversity are supported on the proviso that particular cultural traits (such as language) are adopted for successful integration into civic life (employment, educational institutions, legal literacy etc). Such attitudes reflect an unfinished or under-developed multicultural project, in which the reach of policy and ways of perceiving Australia require further enhancement. 


\section{Identification of 'Out Groups’}

In order to obtain empirical evidence of the perceived 'limits' of cultural diversity, in our survey we asked two sets of questions that delivered data on who might be the current out groups in Australian society. The first set of questions asked respondents if their feelings towards seven specific groups of Australians were positive, negative or neutral (see Table 5 for out group listing). When asked about their feelings towards particular groups, 31.5 per cent of respondents claimed to have 'negative' feelings (including 'somewhat' negative and 'very negative' feelings) towards Muslim Australians, and 22.3 per cent claimed to have 'negative' feelings (including 'somewhat' negative and 'very negative' feelings) towards Middle-Eastern Australians (see Table 5). Several authors have written about what Briskman (2015) terms the 'creeping blight' of Islamophobia in Australia since the September 11 terrorist attacks in 2001 (see for example Morgan and Poynting 2012; Poynting and Mason 2008; Akbarzadeh 2016 ; Aslan 2009). Aslan’s monograph Islamophobia in Australia (2009) argues that in Australia, Islamophobia manifests itself largely as a form of cultural racism that is 'intertwined with a widespread anxiety and resentment felt towards migration and multiculturalism amongst the dominant white Anglo-Celtic Australians' (p. 21). Similarly, Dunn et al. (2007) argue that anti-Muslim attitudes in Australia are 'reproduced through racialisation that includes well-rehearsed stereotypes of Islam' (p. 564) and create a 'culture' rather than 'colour' racism. Their mixed-method research draws on three data sets including qualitative and quantitative responses to three surveys and print media to show how Muslims are constituted as culturally inferior, barbaric, misogynistic, fanatical, intolerant, and ultimately alien. Such widespread negative constructions of Muslims in public and media discourse identified by Dunn et al. (2007) parallel the high rates of negative attitudes towards Muslims and Middle-Eastern Australians in our survey.

Table 5. Attitudes towards specific groups, Australia, 2015-6 ${ }^{1}$

\begin{tabular}{|l|c|c|c|c|c|c|}
\hline & \multicolumn{6}{|c|}{ Attitudinal response } \\
\cline { 2 - 7 } & $\begin{array}{c}\text { Very } \\
\text { positive } \\
\%\end{array}$ & $\begin{array}{c}\text { Somewhat } \\
\text { positive } \\
\%\end{array}$ & $\begin{array}{c}\text { Neutral } \\
\%\end{array}$ & $\begin{array}{c}\text { Somewhat } \\
\text { negative } \\
\%\end{array}$ & $\begin{array}{c}\text { Very } \\
\text { negative } \\
\%\end{array}$ & $\begin{array}{c}\text { Total } \\
\%\end{array}$ \\
\hline $\begin{array}{l}\text { Anglo- } \\
\text { Australians }\end{array}$ & 28.8 & 30.9 & 37.3 & 2.4 & 0.5 & 100 \\
\hline $\begin{array}{l}\text { Aboriginal } \\
\text { Australians }\end{array}$ & 21.7 & 28.1 & 39.9 & 8.4 & 1.9 & 100 \\
\hline $\begin{array}{l}\text { Muslim } \\
\text { Australians }\end{array}$ & 12.3 & 17.9 & 38.3 & 21.1 & 10.4 & 100 \\
\hline $\begin{array}{l}\text { Refugees in } \\
\text { Australia }\end{array}$ & 14.3 & 22.0 & 44.3 & 14.4 & 5.0 & 100 \\
\hline $\begin{array}{l}\text { Middle- } \\
\text { Eastern } \\
\text { Australians }\end{array}$ & 14.4 & 21.5 & 41.7 & 16.7 & 5.6 & 100 \\
\hline $\begin{array}{l}\text { African } \\
\text { Australians }\end{array}$ & 15.8 & 22.6 & 45.5 & 12.2 & 3.9 & 100 \\
\hline $\begin{array}{l}\text { Asian } \\
\text { Australians }\end{array}$ & 22.0 & 31.3 & 39.8 & 5.8 & 1.1 & 100 \\
\hline
\end{tabular}

${ }^{1}$ Question wordings: 'Would you say your feelings are positive, negative or neutral towards the following group...'

Source: Challenging Racism Project Survey, July-August 2015 and November 2016. 
Respondents' feelings towards Anglo-Australians and Asian Australians were the most positive at 59.7 per cent and 53.3 per cent of respondents reporting positive dispositions towards the two groups, respectively. Given Australia's White settler history and continued privilege of Anglo-Australians (Hage 1998), the positive attitudes towards Anglo-Australians are not surprising. However, such positive attitudes towards Asian Australians provides a counterpoint to Australia's long history of anti-Asian sentiment and recent research that suggests that anti-Asian sentiment, related to the cultural, geopolitical and economic swing towards Asia, and particularly China in the 'Asian century', is re-emerging (see for example Rogers et al. 2017). Similarly, the more positive dispositions towards Asian Australians found in our survey also contradicts experiential data that were collected and indicates Chinese Australians report experiences of racism at more than double the average for all Australians: in the workplace, education, housing and other spheres (Blair et al. 2017).

The second set of questions that aimed to deliver data on who might be the current out groups in Australian society utilised a Bogardus social distance instrument (see Bogardus 1933). This instrument was used to measure the degree of intolerance of specific out groups by asking about the out-marriage of a family member. Such Bogardus social distance measures have also been referred to as 'comfort' or distance indicators in other attitudinal survey work (see Peach 1976; Berry \& Kalin 1995, pp. 306-7; Dunn et al. 2004) and have traditionally been analysed as indicators of (in)tolerance (Dunn 2004). In our survey, respondents were asked the extent of their concern, if any, if a close relative were to marry a member of ten specific groups (see Table 6).

Table 6. Levels of concern regarding out-marriage of a relative, to specific groups, Australia, 2015-6 ${ }^{1}$

\begin{tabular}{|c|c|c|c|c|c|c|}
\hline & \multicolumn{5}{|c|}{ Level of concern } \\
\cline { 2 - 7 } & $\begin{array}{c}\text { Not at all } \\
\text { concerned } \\
\%\end{array}$ & $\begin{array}{c}\text { Slightly } \\
\text { concerned } \\
\%\end{array}$ & $\begin{array}{c}\text { Somewhat } \\
\text { concerned } \\
\%\end{array}$ & $\begin{array}{c}\text { Very } \\
\text { concerned } \\
\%\end{array}$ & $\begin{array}{c}\text { Extremely } \\
\text { concerned } \\
\%\end{array}$ & $\begin{array}{c}\text { Total } \\
\%\end{array}$ \\
\hline $\begin{array}{c}\text { Indian, } \\
\text { Pakistani or } \\
\text { Sri Lankan } \\
\text { backgrounds }\end{array}$ & 61.6 & 18.4 & 12.0 & 4.7 & 3.4 & 100 \\
\hline $\begin{array}{c}\text { Other Asian } \\
\text { backgrounds }\end{array}$ & 70.4 & 15.4 & 9.1 & 3.3 & 1.8 & 100 \\
\hline $\begin{array}{c}\text { Aboriginal } \\
\text { background }\end{array}$ & 63.8 & 17.2 & 10.9 & 4.8 & 3.2 & 100 \\
\hline $\begin{array}{c}\text { Italian } \\
\text { background }\end{array}$ & 81.6 & 9.5 & 6.1 & 1.8 & 0.9 & 100 \\
\hline $\begin{array}{c}\text { British } \\
\text { background }\end{array}$ & 84.1 & 7.5 & 5.6 & 1.9 & 0.8 & 100 \\
\hline $\begin{array}{c}\text { African } \\
\text { background }\end{array}$ & 56.1 & 19.1 & 12.4 & 7.2 & 5.2 & 100 \\
\hline $\begin{array}{c}\text { Middle Eastern } \\
\text { background }\end{array}$ & 48.6 & 19.8 & 14.3 & 9.4 & 7.9 & 100 \\
\hline Muslim Faith & 36.9 & 19.7 & 15.6 & 10.4 & 17.2 & 100 \\
\hline Jewish Faith & 59.9 & 17.7 & 12.4 & 5.5 & 4.4 & 100 \\
\hline $\begin{array}{c}\text { Christian } \\
\text { Faith }\end{array}$ & 77.3 & 10.7 & 7.6 & 2.5 & 1.9 & 100 \\
\hline
\end{tabular}

${ }^{1}$ Question wording: 'In your opinion, how concerned would you feel if one of your closest relatives were to marry a person of...’

Source: Challenging Racism Project Survey, July-August 2015 and November 2016. 
This second set of questions elucidated a higher degree of intolerance or negative attitudes towards specific groups of Australians. For example, there is a substantive level of stated concern regarding Muslim Australians. Only 36.9 per cent of respondents replied they would not be concerned at all if a relative married an individual of Muslim faith while 27.6 per cent indicated they would be 'extremely' or 'very concerned' if a relative were to marry a Muslim. This constituted one-in-four respondents. In total, 62.9 per cent of respondents expressed some degree (ranging from slightly-extremely) of intolerance/ discomfort with Muslim Australians further elucidating the extent of anti-Islamic/Islamaphobic within the Australian population (Table 6).

Middle Eastern and African Australians were also perceived as significant out groups. One-in-two respondents (51.4 per cent) expressed some level of concern (slight concern to extreme concern) if a relative were to marry someone of Middle Eastern background, and 43.9 per cent of respondents expressed some level of concern (slight concern to extreme concern) if a relative were to marry someone of African background. Other significant outgroups included Southern Asian (Indian, Pakistani or Sri Lankan) and Jewish Australians, with 38.4 per cent of respondents expressing some anti-Southern Asian sentiment and 40.1 per cent expressing some anti-Jewish sentiment (Table 6). Respondents were also prompted to indicate their tolerance or comfort with British, Christian and Italian Australians. AntiBritish and anti-Italian sentiment (from 'slight' through to 'extreme' concern) were lowest across the sample at only 15.9 per cent and 18.4 per cent, respectively. Anti-Christian sentiment was also relatively low at 22.7 per cent (see Table 6). These results indicate the culturally uneven nature of tolerance in Australia and the continued and pervasive impact of 'White' (and Christian) privilege and normalisation within the Australian psyche (see Goodall et al. 1994; Hage 1998; Wilson and Gibson 2003; Fozdar 2011; Nelson et al. 2012; Blair 2015).

Female respondents were generally more tolerant of inter-marriage with all the groups identified above. This was especially true for marriage with Aboriginal Australians, African Australians and Jewish Australians in which the gender differences in responses was statistically significant (see Table 7). For marriage with Middle Eastern, Asian (both South and 'Other Asian') and Muslim Australians the gender variation was not statistically significant. Male respondents were also more likely to express concern regarding intermarriage with Italian Australians, British Australians and Christian Australians. Older people, especially those over 65 years old, had greater intolerance by this measure, particularly in regards to Middle Eastern, Muslim and African Australians (see Table 7). 
Table 7 Any Stated Concern Regarding Inter-Marriage to Selected 'out groups', by gender and age, Australia, 2015-6

\begin{tabular}{|c|c|c|c|c|c|c|c|c|c|}
\hline & \multicolumn{4}{|c|}{ Gender } & \multicolumn{5}{|c|}{ Age } \\
\hline & Male & Female & $\begin{array}{l}\text { Chi- } \\
\text { Sq }\end{array}$ & $\begin{array}{c}\text { P- } \\
\text { value }^{2}\end{array}$ & $\begin{array}{l}18- \\
35\end{array}$ & $\begin{array}{l}36- \\
65\end{array}$ & $\begin{array}{c}\text { Over } \\
65\end{array}$ & Chi-sq & $\begin{array}{c}\mathrm{P} \text { - } \\
\text { value }\end{array}$ \\
\hline $\begin{array}{c}\text { South } \\
\text { Asian } \\
\%\end{array}$ & 38.7 & 38.2 & .183 & .669 & 38.2 & 36.4 & 45.2 & 24.832 & .000 \\
\hline $\begin{array}{c}\text { Other } \\
\text { Asian } \\
\%\end{array}$ & 30.7 & 28.6 & 3.041 & 0.81 & 27.5 & 28.6 & 37.1 & 32.846 & .000 \\
\hline $\begin{array}{c}\text { Aboriginal } \\
\%\end{array}$ & 39.1 & 33.4 & 20.542 & .000 & 37.6 & 32.4 & 44.4 & 49.194 & .000 \\
\hline $\begin{array}{c}\text { Italian } \\
\%\end{array}$ & 20.4 & 16.5 & 15.065 & .000 & 22.1 & 16.4 & 16.7 & 28.426 & .000 \\
\hline $\begin{array}{c}\text { British } \\
\%\end{array}$ & 18.0 & 13.9 & 18.118 & .000 & 20.9 & 14.8 & 8.7 & 78.988 & .000 \\
\hline $\begin{array}{c}\text { African } \\
\%\end{array}$ & 46.6 & 41.4 & 16.902 & .000 & 39.5 & 42.5 & 57.2 & 89.705 & .000 \\
\hline $\begin{array}{c}\text { Middle } \\
\text { Eastern } \\
\%\end{array}$ & 51.8 & 51.0 & .407 & .524 & 45.4 & 51.2 & 34.2 & 94.602 & .000 \\
\hline $\begin{array}{c}\text { Muslim } \\
\%\end{array}$ & 64.0 & 62.2 & 2.076 & .150 & 56.1 & 62.7 & 78.4 & 143.112 & .000 \\
\hline $\begin{array}{c}\text { Jewish } \\
\%\end{array}$ & 43.0 & 37.4 & 19.228 & .000 & 40.1 & 38.2 & 45.4 & 15.977 & .000 \\
\hline $\begin{array}{c}\text { Christian } \\
\%\end{array}$ & 24.6 & 20.9 & 11.495 & .001 & 29.5 & 21.2 & 13.3 & 108.052 & .000 \\
\hline $\begin{array}{l}{ }^{1} \text { Question } \\
\text { relatives we } \\
{ }^{2} \text { Probability } \\
\text { set at } \mathrm{p}<.0\end{array}$ & va & our & $\begin{array}{l}\text { on, hov } \\
\text { f...' } \\
\text { lated us }\end{array}$ & ncer & wou & you & if $c$ & $\begin{array}{l}\text { f your } \\
\text { icance }\end{array}$ & $\begin{array}{l}\text { est } \\
\text { shold }\end{array}$ \\
\hline
\end{tabular}

\section{Perception of Migrant Intakes}

Data from the 2016 Australian national census indicates that one-third (33.3 per cent) of Australians are migrants, having been born in a country other than Australia (ABS 2017). The migrant characteristic of Australia's current population is also reflected in the birthplace of parents, that is, 34.4 per cent of Australians have parents that were both born overseas, and an additional 11.1 per cent of Australians have one parent born overseas (ABS 2017). Despite the large proportion of migrants and children of migrants that make up the Australian population (and not forgetting the long history of migrant intake since European settlement) there have, throughout Australia's European history, been ongoing social, political and economic anxieties about the type and amount of migrants that the nation can sustain (Walker 1999). As outlined in the introduction to this article, such anxieties have recently manifest in proposed and actual changes to Australia's migration and multiculturalism policies, and government and media discourses that vilify asylum seekers, particularly those arriving by sea (Every and Augoustinos 2007; McKay et al. 2012, Trounson et al. 2015). 
Within this climate, we deemed it important to ask survey participants how they felt about the current intake of immigrants in order to obtain empirical evidence of 'every day' Australians' views. While the majority (46.4 per cent) of respondents felt that intake was 'about right', 36.6 per cent felt that it was either too high or much too high (see Table 8). In contrast to the previous attitudinal indicators, females, more so than males, and 36-45 year olds, more so than those over 65 years of age and those between 18-35 years of age, were more likely to state that the immigration intake was too high. It is not clear why this gender and age 'reversal' was produced in the results but it may point to increased anxieties within these demographic groups to perceived issues relating migrant intakes such as threats to job security/high unemployment, population growth, and social welfare issues (as discussed in Betts' (2002) explanation for shifting attitudes to immigration in Australia since the 1990s). More detailed research would help shed light on this attitudinal variation. Australian born and those who speak only English were also more likely to state that the intake was too high, in comparison to overseas born and those respondents of a LOTE background (Table 8).

Table 8. Attitudes towards immigration intake, Australia, 2015-6

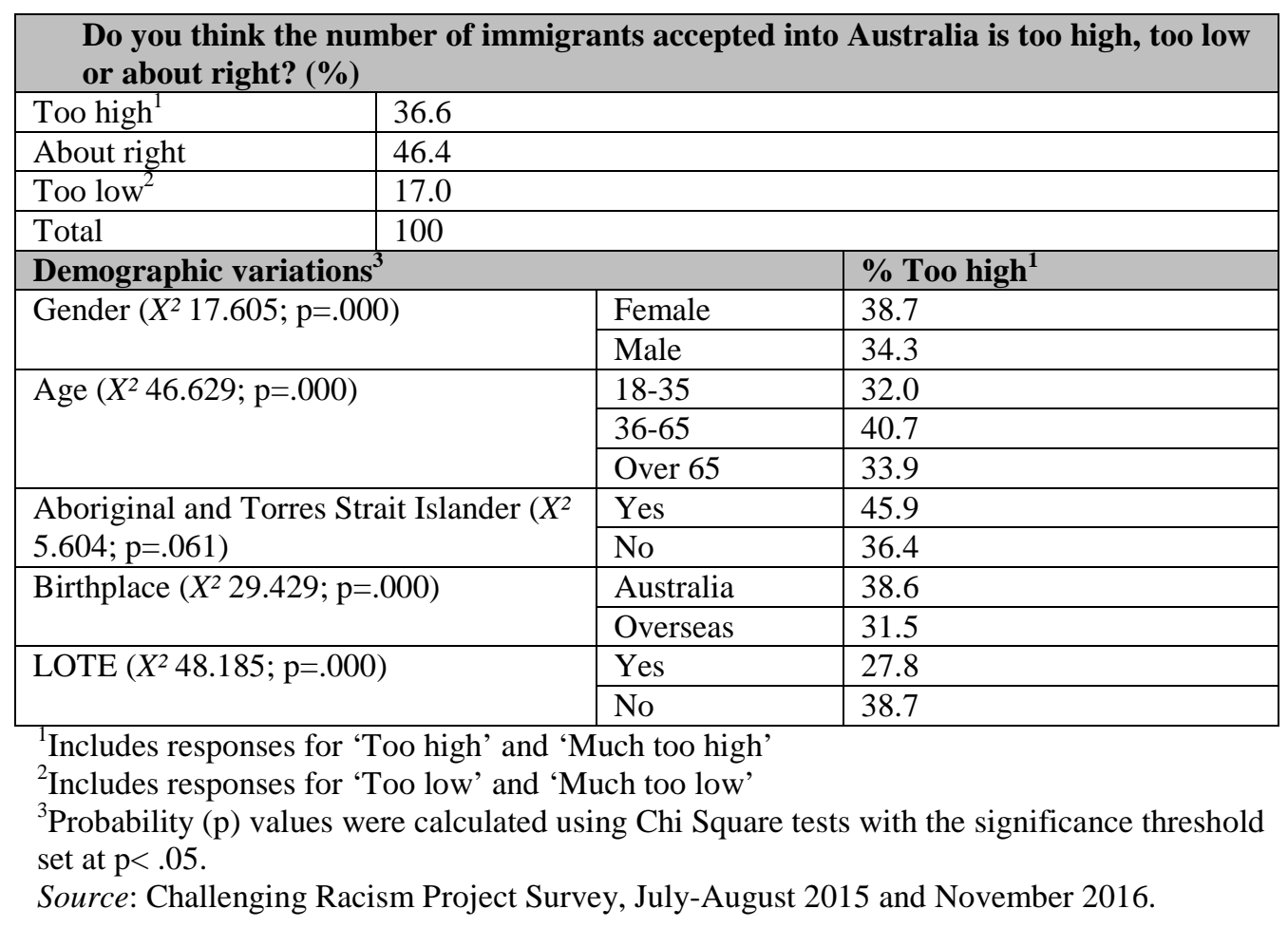

Unsurprisingly, those participants who felt the immigration intake was too high were also less likely to hold positive attitudes toward diversity. For example, of those respondents who were positive about immigration (stating that Australian immigration intake is 'too low/much too low'), 95.6 per cent also agreed that it is a good thing for society to be made up of different cultures. In contrast, a much smaller proportion (67.7 per cent) of respondents who believed that Australian immigration intake is 'too high/much too high' also agreed that it is a good thing for society to be made up of different cultures (see Table 9). Chi-Square testing indicates that this relationship between perception of immigrant intake and support for cultural diversity is statistically significant ( $X^{2}$ 458.668; $\mathrm{p}=.000$ ). A similarly significant 
pattern was seen in participant responses to the immigration question and agreement that a multicultural population has been good for Australia, that is, 93.9 per cent of participants that believed immigration is 'too low/much too low' also agreed that multiculturalism is good for Australia( $\left.X^{2} 830.561\right)$. However, only 56.0 per cent of participants that believed immigration is 'too high/much too high' agreed with the benefits of multiculturalism (see Table 9). In regards to the question of assimilation, the pattern remains clear: the large majority (69.7 per cent) of participants who believed immigration is 'too high/much too high' also agreed that 'people from racial, ethnic, cultural and religious minority groups should behave more like mainstream Australians'. This compares to a minority (21.0 per cent) of participants who believe immigration intake is 'too low/much too low' (Table 9). Attitudes about diversity and multiculturalism are associated, for many Australians, with their dispositions towards migration policy and programs.

Table 9: Relationship between attitudes towards cultural diversity and immigration intake, Australia, 2015-6 ${ }^{1}$

\begin{tabular}{|l|l|c|c|}
\hline \multicolumn{2}{|l|}{} & $\begin{array}{l}\text { Immigration } \\
\text { 'too high, }\end{array}$ & $\begin{array}{l}\text { Immigration } \\
\text { ' } \text { too low' }^{2}\end{array}$ \\
\hline $\begin{array}{l}\text { It is a good thing for a society to be made up of } \\
\text { different cultures } \\
\left(X^{2} \text { 458.668; } \mathrm{p}=.000\right)\end{array}$ & Agree & $67.7 \%$ & $95.6 \%$ \\
\hline $\begin{array}{l}\text { Having a multicultural population has been } \\
\text { good for Australia } \\
\left(X^{2} \text { 830.561; } \mathrm{p}=.000\right)\end{array}$ & Agree & $56.0 \%$ & $93.9 \%$ \\
\hline $\begin{array}{l}\text { People from racial, ethnic, cultural and religious } \\
\text { minority groups should behave more like } \\
\text { mainstream Australians } \\
\left(X^{2} \text { 986.868; } p=.000\right)\end{array}$ & Agree & $69.7 \%$ & $21.0 \%$ \\
\hline
\end{tabular}

${ }^{1}$ Data contained in this table have been drawn from three crosstabulations and their Pearson's chi squared $\left(X^{2}\right)$ and significance testing. The crosstabulations were used to summarise the relationship between responses to 'Do you think the number of immigrants accepted into Australia is too high, too low or about right?' and responses to the three survey questions listed in the table. Probability (p) values were calculated using Chi Square tests with the significance threshold set at $\mathrm{p}<.05$.

${ }^{2}$ Question wording: Do you think the number of immigrations accepted into Australia is too high, too low or about right?

Source: Challenging Racism Project Survey, July-August 2015 and November 2016.

Participants were also asked about their views on discriminatory migration policy via the questionnaire statement: 'All migrants should be accepted regardless of where they come from'. Just over half of the respondents (53.3 per cent) believed all migrants should be accepted to Australia irrespective of their country of birth (see Table 10). However, a sizeable proportion of the participants, 23.4 per cent, disagreed with this proposition. Again, males (26.9 per cent) were more likely than females (20.1 per cent) to support discriminatory immigration policy, as were older participants, the Australian born and those who speak only English (see Table 10). Higher education was linked to less exclusionary attitudes, that is, those with non-tertiary education levels were more likely to support a discriminatory immigration policy than those with a tertiary education (see Table 10). 
Table 10. Attitudes towards discriminatory migration policy, Australia, 2015-6

\begin{tabular}{|c|c|c|c|}
\hline \multicolumn{4}{|c|}{ All migrants should be accepted regardless of where they come from (\%) } \\
\hline Agree $^{1}$ & \multicolumn{3}{|l|}{53.3} \\
\hline $\begin{array}{l}\text { Neither } \\
\text { agree/disagree }\end{array}$ & \multicolumn{3}{|l|}{23.4} \\
\hline Disagree $^{2}$ & \multicolumn{3}{|l|}{23.4} \\
\hline Total & \multicolumn{3}{|l|}{100} \\
\hline \multicolumn{3}{|c|}{ Demographic variations $^{3}$} & \% Disgree ${ }^{2}$ \\
\hline \multirow{2}{*}{\multicolumn{2}{|c|}{ Gender $\left(\mathrm{X}^{2} 38.486 ; \mathrm{p}=.000\right)$}} & Female & 20.1 \\
\hline & & Male & 26.9 \\
\hline \multirow{3}{*}{\multicolumn{2}{|c|}{ Age $\left(\mathrm{X}^{2} 117.081 ; \mathrm{p}=.000\right)$}} & $18-35$ & 16.5 \\
\hline & & $36-65$ & 24.7 \\
\hline & & Over 65 & 33.7 \\
\hline \multirow{2}{*}{\multicolumn{2}{|c|}{$\begin{array}{l}\text { Aboriginal and Torres Strait Islander }\left(\mathrm{X}^{2} 2.108 ;\right. \\
\mathrm{p}=.348)\end{array}$}} & Yes & 18.5 \\
\hline & & No & 23.5 \\
\hline \multirow{2}{*}{\multicolumn{2}{|c|}{ Birthplace $\left(X^{2} 44.068 ; p=.000\right)$}} & Australia & 25.1 \\
\hline & & Overseas & 19.0 \\
\hline \multirow{2}{*}{\multicolumn{2}{|c|}{ LOTE $\left(X^{2}\right.$ 92.163; $\left.\mathrm{p}=.000\right)$}} & Yes & 13.9 \\
\hline & & No & 25.5 \\
\hline \multirow{2}{*}{\multicolumn{2}{|c|}{ Education $\left(\mathrm{X}^{2} 22.847 ; \mathrm{p}=.000\right)$}} & Tertiary & 22.9 \\
\hline & & Non-tertiary & 24.4 \\
\hline \multicolumn{4}{|c|}{${ }^{1}$ Includes responses for 'Agree' and 'Strongly Agree' } \\
\hline \multicolumn{4}{|c|}{ 2Includes responses for 'Disagree' and 'Strongly Disagree' } \\
\hline \multicolumn{4}{|c|}{$\begin{array}{l}{ }^{3} \text { Probability (p) values were calculated using Chi Square tests with the significance threshold } \\
\text { set at } p<.05 \text {. }\end{array}$} \\
\hline
\end{tabular}

\section{Conclusions}

The Challenging Racism Project Survey provides one of the most recent and large-scale national-level sources of data on Australians' attitudes toward cultural diversity, nation and migration. Analysis of the survey results indicate that respondents were largely supportive of cultural diversity, with the majority of the 6001 participants agreeing that 'it is a good thing for a society to be made up of different cultures' and 'having a multicultural population has been good for Australia'. Similarly, the majority of participants were supportive of the size of Australia's current immigrant intake and the acceptance of immigrants regardless of where they come from. These positive findings align with previous research that has found that Australians are generally supportive of cultural diversity and immigration. However, despite majority support for cultural diversity and multiculturalism there was contradictory support for assimilation with almost half of the participants agreeing that people from racial, ethnic, cultural and religious minority groups should behave more like 'mainstream Australians'. Approximately 40 per cent of participants also agreed that 'Australia is weakened by people of different ethnic origins sticking to their old ways'. As suggested by Dunn et al. (2010), such contradictory support for cultural and racial pluralism alongside concerns about diversity point to anxieties about cultural difference, and perhaps point to the 'limits' of multiculturalism and the extent to which cultural diversity can be successful/beneficial to the nation. Further research, particularly in-depth qualitative discussions, may shed light on such apparent concerns or anxieties about cultural difference.

Concerns about cultural diversity were also apparent in the survey results relating to the identification of 'out groups'. Respondents indicated a substantive level of concern regarding 
Muslim Australians. This is unsurprising given the current climate of increased Islamophobia and the associated increase in racist incidents targeted at Muslim Australians (Briskman 2015; Morgan and Poynting 2012; Poynting and Mason 2008; Akbarzadeh 2016 ; Aslan 2009; Dunn et al. 2010; HREOC 2004; IWWCV 2008). Middle Eastern, African Australians, Southern Asian (Indian, Pakistani or Sri Lankan) and Jewish Australians were also perceived as significant out groups. Respondents' feelings towards Anglo-Australians were the most positive; pointing to the ongoing normalisation of constructions of 'White'/Anglo Australian national identity and belonging.

Such negative perceptions of particular groups within the multicultural landscape are problematic as they have 'the potential to generate substantial inter-communal tensions in the workplaces and other public realms of Australian society’ (Dunn et al. 2004, p.425) as evidenced in everyday experiences of racism and marginalisation (Essed 1991; Essed 2002; Dunn et al.2007; Fozdar and Terezani 2008; Dunn et al. 2015; Rajendran 2017). Therefore, we reiterate Dunn et al.'s (2004) assertion from over a decade ago that 'the confrontation of this sociobiological and pessimistic [and narrow] understanding of nation remains an unfinished public policy imperative of Australian multicultural policy' (p.426). One avenue for change must be a more strident reimagining of 'a culturally inclusive, diverse and dynamic articulation of nation' that is engrained in public discourse and educational initiatives (Dunn et al. 2004, p.426).

Overall, female participants were more likely than male participants to be supportive of cultural diversity and more tolerant of inter-marriage between various cultural groups. In general, younger Australians between the ages of 18 and 35 have more positive attitudes towards cultural diversity and inter-marriage than participants over 35 (particularly more so than participants over 65 years of age). This difference across the age groups may reflect the success of anti-racist and pro-multicultural initiatives in schools (as also suggested by Dunn et al. 2004) and across social media and other public spheres in recent decades. The antipathies held by the older generation of participants will be a reflection of the enduring legacies of the White Australia Policy era and its associated discourses of White national identity, assimilation and uneven rights to 'belong'. Further research would provide empirical evidence for such differences across the generations.

While it is clear that perceptions of cultural diversity, migration and nation continue to be uneven across various demographic cohorts, the large extent of positive attitudes among the majority of participants suggests that anti-racist initiatives and multicultural definitions of national identity are having real impacts on Australians' understandings of nation and national belonging. Therefore the public policy implication that education initiatives and public pronouncements advocating multiculturalism and cultural diversity have important roles to play (as advocated by Dunn et al. 2004, p.426) is still highly relevant and necessary within the contemporary Australian multicultural context which continues to be complicated by political initiatives and policy arguments, social movements (particularly of the far right) and media commentary that at times undermine the demographic reality of cultural diversity in Australia. 


\section{References}

Akbarzadeh, S. 2016, 'The Muslim Question in Australia: Islamophobia and Muslim Alienation', Journal of Muslim Minority Affairs, vol.36, no.3, pp. 323-333. https://doi.org/10.1080/13602004.2016.1212493

Ang, I., Brand, J., Noble, G. \& Wilding, G. 2002, Living Diversity: Australia’s Multicultural Future, Special Broadcasting Service (SBS), Artarmon.

Ang, I., Brand, J., Noble, G. \& Sternberg, J. 2006, Connecting Diversity: Paradoxes of Multicultural Australia, Special Broadcasting Service, Artarmon.

Aslan, A. 2009, Islamophobia in Australia, Agora Press, Glebe.

Augoustinos, M. \& Quinn , C. 2003, 'Social categorization and attitudinal evaluations: illegal immigrants, refugees, or asylum seekers?’, New Review of Social Psychology, vol. 2, pp.29-57.

Australia. Racial Discrimination Act 1975, s.18C (Cth)

Australian Bureau of Statistics. 2017a, 2015-2016 Migration: Australia, Australian Bureau of Statistics, http://www.abs.gov.au/ausstats/abs@.nsf/mf/3412.0

Australian Bureau of Statistics. 2017b, 2016 Census QuickStats: Australia, Australian Bureau of Statistics, http://www.censusdata.abs.gov.au

Baker, R., Blumberg, S.J., Brick, J.M., Couper, M.P., Courtright, M., Dennis, J.M., Dillman, D., Frankel, M.R., Garland, P., Groves, R.M., Kennedy, C., Krosnick, J., Lavrakas, P.J., Lee, S., Link, M., Piekarski, L., Rao, K., Thomas, R.K., Zahs, D. 2010, 'Research Synthesis: AAPOR Report on Online Panels', Public Opinion Quarterly, vol. 74, no. 4, pp. 711-781. https://doi.org/10.1093/poq/nfq048

Betts, K. 1996, 'Immigration and public opinion in Australia [1961 to 1996]', People and Place, vol.4, no.3, pp. 9-20.

Betts, K. 2002, 'Immigration and public opinion: Understanding the shift', People and Place, vol. 10 no, 4, pp.24-37.

Berry, J.W. \& Kalin, R. 1995, 'Multicultural and ethnic attitudes in Canada: an overview of the 1991 national survey', Canadian Journal of Behavioural Science, vol.27, no.3, pp.301-20.https://doi.org/10.1037/0008-400X.27.3.301

Blair, K. 2017, Face Up To Racism: 2015-16 National Survey (Technical Manual), Western Sydney University, https://www.westernsydney.edu.au/__data/assets/pdf_file/0009/1201005/Technical_ Manual_FINAL.pdf

Blair, K. 2015, 'Young adults' attitudes towards multiculturalism in Australia: Tensions between the multicultural state and the intercultural citizen', Journal of Intercultural Studies, vol. 36, no. 4, pp. 431-449. https://doi.org/10.1080/07256868.2015.1049983

Blair, K., Dunn, K., Kamp, A. \& Alam, O. 2017, Challenging Racism Project: 2015-16 National Survey, Western Sydney University. doi:10.4225/35/58cb62d270392

Bogardus, E.S. 1933, ‘A social distance scale’, Sociology \& Social Research, vol. 17, pp.265271.

Briskman, L. 2015, 'The creeping blight of Islamophobia in Australia', International Journal for Crime, Justice and Social Democracy, vol. 4, no.3, 112-121. https://doi.org/10.5204/ijcjsd.v4i3.244. 
Castles, S. 1997, 'Multicultural citizenship: A response to the dilemma of globalisation and national identity?’ Journal of Intercultural Studies, vol.18, no.1, pp. 5-22. https://doi.org/10.1080/07256868.1997.9963438

Callegaro, M., Villar, A., Yeager, D. \& Krosnick, J. A. 2014, 'A critical review of studies investigating the quality of data obtained with online panels based on probability and nonprobability samples, in M. Callegaro,M., Baker,R., Bethlehem, J., Göritz, A.S., Krosnick, J.A. \& Lavrakas, P.J. (eds.), Online Panel Research: A Data Quality Perspective (eds), John Wiley \& Sons, Ltd, Chichester, pp.25-53. https://doi.org/10.1002/9781118763520.ch2.

Curthoys, A. 2000, 'An uneasy conversation: the multicultural and the Indigenous', in Docker, J. \& Fischer, G. (eds.). Race, Colour and Identity in Australia and New Zealand, UNSW Press, Sydney, pp. 21-36.

Dandy, J. \& Pe-Pua, R. 2010, 'Attitudes to multiculturalism, immigration and cultural diversity: Comparison of dominant and non-dominant groups in three Australian states', International Journal of Intercultural Relations, vol.34, no.1, pp. 34-46. https://doi.org/10.1016/j.ijintrel.2009.10.003

Department of Immigration and Border Protection. 2017, Abolition and replacement of the 457 visa - Government reforms to employer sponsored skilled migration. https://www.border.gov.au/Trav/Work/457-abolition-replacement

Dunn, K., Forrest, J., Burnley, I. \& McDonald, A. 2004, 'Constructing racism in Australia', Australian Journal of Social Issues, vol. 39, no. 4, pp. 409-30. https://doi.org/10.1002/j.1839-4655.2004.tb01191.x

Dunn, K, Forrest, J, Pe-Pua, R, Hynes, M \& Maeder-Han, K. 2009, 'Cities of race hatred? The spheres of racism and anti-racism in contemporary Australian cities', Cosmopolitan Civil Societies: An Interdisciplinary Journal, vol. 1, no. 1, pp. 1-14. https://doi.org/10.5130/ccs.v1i1.833

Dunn, K. M., Atie, R., Mapedzahama, V., Ozalp, M. \& Aydogan, A. F. 2015, The resilience and ordinariness of Australian Muslims: Attitudes and experiences of Muslims report, Western Sydney University, Islamic Sciences and Research Academy, Charles Sturt University, Sydney, Australia.

Dunn, K., Kamp, A., Shaw, W., Forrest, J. \& Paradies, Y. 2010, 'Indigenous Australians' attitudes towards multiculturalism, cultural diversity, 'race' and racism', Journal of Australian Indigenous Issues, vol. 13, no. 4, pp. 19-31.

Dunn, K., Klocker, N. \& Salabay, T. 2007, 'Contemporary racism and Islamaphobia in Australia: Racialising religion’, Ethnicities, vol. 7, no. 4, pp. 564-89. https://doi.org/10.1177/1468796807084017

Essed, P. 1991, Understanding Everyday Racism: An Interdisciplinary Theory, Sage, Newbury Park. https://doi.org/10.4135/9781483345239.

Essed, P. 2002, 'Everyday racism', in Goldberg, D.T. and Solomos, J. (eds.), A Companion to Racial and Ethnic Studies, Blackwell, Malden, MA, pp. 202-216.

Every, D. \& Augoustinos, M. 2007, 'Constructions of racism in the Australian parliamentary debates on asylum seekers', Discourse \& Society, vol. 18, no.4, pp.411-436. https://doi.org/10.1177/0957926507077427 
Fozdar, F. \& Torezani, S. 2008, 'Discrimination and well-being: Perceptions of refugees in Western Australia’, International Migration Review, vol. 42, no. 1, pp. 30-63. https://doi.org/10.1111/j.1747-7379.2007.00113.x

Fozdar, F. 2011, 'The Choir Boy and the Mad Monk: Christianity, Islam, Australia's political landscape and prospects for multiculturalism', Journal of Intercultural Studies, vol. 32, no. 6, pp. 621-636. https://doi.org/10.1080/07256868.2011.618107

Goodall, H. et al. 1994, Racism, Ethnicity and the Media, Allen and Unwin, Sydney.

Hage, G. 1998, White Nation: Fantasies of White Supremacy in a Multicultural Society, Pluto Press, Annandale.

Ho, R. 1990, 'Multiculturalism in Australia: A survey of attitudes', Human Relations, vol. 43, no.3, pp. 259-272. https://doi.org/10.1177/001872679004300304

Human Rights and Equal Opportunity Commission (HREOC) 2004, Ismaع - Listen: National consultations on eliminating Prejudice against Arab and Muslim Australians, https://www.humanrights.gov.au/publications/isma-listen-report

Islamic Women’s Welfare Council Victoria (IWWCV) 2008, 'Race, faith and gender: converging discriminations against Muslim women in Victoria', http://www.australianmuslimwomen.org.au/uploads/3/9/5/0/3950888/iwwcv_race_fait h_report.pdf

Jayasuriya, L. 2002, 'Understanding Australian racism', Australian Universities Review, vol. 45, no.1, pp.40-44.

Markus, A. 2014, 'Attitudes to immigration and cultural diversity in Australia', Journal of Sociology, vol.50, no.1, pp.10-12. https://doi.org/10.1177/1440783314522188

Markus, A. 2016, Mapping Social Cohesion: The Scanlon Foundation Surveys, ACJC, Faculty of Arts, Monash University.

McAllister, I. 1993, 'Immigration, bipartisanship and public opinion’, in Jupp, J. \& Kabala, M. (eds.) The Politics of Immigration, Bureau of Immigration Research, Melbourne.

McGregor, R. 2011, Indifferent Inclusion: Aboriginal People and the Australian Nation, Aboriginal Studies Press, Canberra.

McKay, F. H., Thomas, S. L. \& Kneebone, S. 2012, “"It would be okay if they came through the proper channels": Community perceptions and attitudes toward asylum seekers in Australia', Journal of Refugee Studies, vol.25, no.1, pp.113-133. https://doi.org/10.1093/jrs/fer010

Moore, T. 2014, 'Aboriginal agency and marginalisation in Australian Society', Social Inclusion, vol.2, issue 3, pp.124-135. https://doi.org/10.17645/si.v2i3.38

Morgan, G., \& Poynting, S. 2012, 'Introduction: The transnational folk devil', in Morgan, G. \& Poynting, S. (eds) Global Islamophobia: Muslims and moral panic in the West, Ashgate, Farnham, pp. 1-14. https://doi.org/10.1017/S0570608412000014

Morrissey, M. \& Mitchell, C. 1994, Community Relations Strategy: An Evaluation, Australian Government Publishing Service, Canberra.

Nelson, J. \& Dunn, K. 2013, 'Racism and anti-racism’ in Jakubowicz, A. \& Ho, C. (eds) Australian Multicultural Theory, Policy and Practice, Australian Scholarly Publishing, Melbourne, pp. 259-276.

Nelson, J., Possamai-Inesedy, A. \& Dunn, K. 2012, 'Reinforcing substantive religious inequality: a critical analysis of submissions to the review of freedom of religion and 
belief in Australia inquiry', Australian Journal of Social Issues, vol.47, no.3, pp. 297318. https://doi.org/10.1002/j.1839-4655.2012.tb00250.x

Peach, C. 1976, Urban Social Segregation, Longman, London.

Pedersen, A., Watt, A. \& Hansen, S. 2006, 'The role of false beliefs in the community's and the federal government's attitudes toward Australian asylum seekers', Australian Journal of Social Issues, vol. 41, no. pp.105-124.

Poynting, S. \& Mason, V. 2008, 'The new integrationism, the state and Islamophobia: retreat from multiculturalism in Australia', International Journal of Law, Crime and Justice, vol.36, no.4, pp.230-246. https://doi.org/10.1016/j.ijlcj.2008.08.001

Rajendran, D., Farquharson, K. \& Hewege, C. 2017, 'Workplace integration: the lived experiences of highly skilled migrants in Australia', Equality, Diversity and Inclusion: An International Journal, vol. 36, no. 5, pp.437-456

Reconciliation Australia 2016, 2016 Australian Reconciliation Barometer, Polity Research and Consulting, Sydney.

Rogers, D., Wong, A. \& Nelson, J. 2017, 'Public perceptions of foreign and Chinese real estate investment: intercultural relations in Global Sydney’, Australian Geographer, (published online 8 May 2017) https://doi.org/10.1080/00049182.2017.1317050

Trounson, J. S., Critchley, C. \& Pfeifer, J. E. 2015, 'Australian attitudes toward asylum seekers: Roles of dehumanization and social dominance theory', Social Behavior and Personality: An International Journal, vol.43, no.10, pp. 1641-1655. https://doi.org/10.2224/sbp.2015.43.10.1641

Van den Berg, R. 2002, Nyoongar People of Australia: Perspectives on Racism and Multiculturalism, Brill, Boston.

Walker, D. 1999, Anxious Nation, University of Queensland Press, Brisbane.

Wilson, S. \& Gibson, R. 2003, Australian Survey of Social Attitudes 2003, ACSPRI Centre for Social Research, The Australian National University, Canberra.

Zivic, M. 2017, 'Migrants no longer in limbo as citizenship changes killed off by Senate', SBS, 18 October, viewed 9 November 2017, http://www.sbs.com.au/news/article/2017/10/18/migrants-no-longer-limbocitizenship-changes-killed-senate 
This page intentionally blank 